\title{
Determination of Major Problems of Raw Hide and Soaking Process in Leather Industry
}

\author{
Deri Endüstrisinde Ham Deride ve Islatma İşleminde Karşılaşılan Başlıca Sorunlarının \\ Belirlenmesi \\ Didem BERBER ${ }^{1}$ D, Meral BİRBİR ${ }^{1}$ \\ ${ }^{1}$ Marmara University, Faculty of Arts and Sciences, Department of Biology, Istanbul, Turkey
}

\begin{abstract}
Hide quality is adversely affected during salt-curing and soaking processes especially due to bacterial activities of microorganisms. These organisms may cause irreversible grain damage, pinpricks, disruption of collagen fibers, uneven dyeing that cannot be recovered by leather production process. To determine major problems on salted and soaked skins/hides, a questionnaire study was applied to leather technicians in Istanbul Organized Leather Industrial Zone, Turkey in both 2009 and 2018. While most tanneries were processing hides/skins imported from foreign countries in 2009, local cattle hides are processed in 2018. Conventional salt curing method has been applied in warehouses. The most striking point is that the salt was applied randomly during preservation. Although tanneries do not store rawhide more than one month, there is no information about how long they store in warehouses. The tanneries reported red spots, unpleasant odor, hair slip, loss of elasticity, holes in grain surface, bacterial and fungal growth on skin/hides. Leather-making processes are performed at ambient temperature of tanneries. No difference was observed in application of soaking process in both 2009 and 2018 surveys. This questionnaire study showed that most of problems were related with microbial damage and bloodstain, burns due to manure and flaying mistakes at slaughterhouses.
\end{abstract}

Keywords: skins, hides, leather, questionnaire.

Öz

Derinin kalitesi, özellikle mikroorganizmaların bakteriyel aktivitelerinden dolayı tuzla kürleme ve 1slatma işlemlerinde olumsuz etkilenmektedir. Bu organizmalar çoğunlukla sonraki deri işlenti safhalarında düzeltilemeyen geri dönüşümsüz sırça hasarına, sırça yüzeyinde küçük deliklere, kollajen liflerinin bozulmasına, düzensiz boyamaya neden olabilmektedir. Tuzlanmış ve 1slatılmış küçükbaş ve büyükbaş derilerindeki önemli problemleri belirlemek için, hem 2009 hem de 2018'de İstanbul Organize Deri Sanayi Bölgesi'ndeki deri teknisyenlerine anket uygulanmıştır. Tabakhanelerin 2009 yılında yabancı ülkelerden ithal edilen derileri/postları işlediği, 2018' de ise yerli sı̆̆ır derilerinin işlendiği saptanmıştır. Ham deri depolarında geleneksel tuzlama yöntemi uygulandığı belirlenmiştir. En dikkat çeken nokta ise, ham derilerin muhafazası sırasında tuzun rastgele uygulanmasıdır. Tabakhaneler ham deriyi bir aydan fazla depolamamasına rağmen, ham deri depolarında ne kadar süre depolandıkları hakkında bilgi yoktur. Tabakhaneler deride kırmızı leke, kötü koku, kıl gevşemesi, elastikiyet kaybı, sırça yüzeyindeki delik, bakteri ve mantar oluşumu bildirmiştir. Deri işlenti basamakları, tabakhanelerin ortam sıcaklığında gerçekleştirilmektedir. Hem 2009 hem de 2018 yıllarında yapılan anketlerde 1slatma işleminin uygulanmasında bir fark gözlenmemiştir. Bu anket çalışması, dericilikte karşılaşılan problemlerin çoğunun mikrobiyal hasar, kan lekesi, gübre yanığ1 ve mezbahalarda yapılan hatalar ile ilişskili olduğunu göstermiştir.

Anahtar Kelimeler: küçük baş hayvan derileri, büyük baş hayvan derileri, işlenmiş deri, anket

\section{INTRODUCTION}

Leather and leather goods are one of the most commodities that contribute to the global economy (1). Therefore, leather industry has a great economic importance in numerous developing countries due to many socio-economic aspects, such as 
advanced employability, economic prosperity and rural development. Leather goods are commonly used products in ready-made garment (especially footwear and bags), bookbinding, automotive industry and furniture covering $(2,3)$. In Turkey, leather industry is an export-oriented sector that produces and exports high quality of products with high added value to the world market especially to Russia, Italy, Germany, Iraq, England, France, Spain, Romania, Bulgaria and Saudi Arabia. The tanneries that process hides or skins are located in organized leather industrial zones in Istanbul-Tuzla, Tekirdag-Çorlu, Bursa, Uşak, Manisa, Denizli, Balıkesir-Gönen and Bolu-Gerede (4,5). According to the report of Istanbul Textile and Apparel Exporters' Associations (ITKIB) on Leather and Leather Product Sector (2018), the total export value of Turkey in leather and leather product increased an average annual rate of $25.3 \%$ from 2017 to 2018. Turkey's exports in the leather products were estimated to reach US\$ 145.2 billion (5).

Leather industry in Turkey aims to meet leather demand of the country, contribute to economy by exporting, and develop to produce best quality of leather at the maximum level by using modern technologies. While there has been a significant decline in the number of manufacturers of leather tanning and processing since 2005, large companies have been able to survive (6). In most of the tanneries (more than $90 \%$ ), maximum 20 people have been reported to work. It is obvious that this export potential of Turkish leather industry may be developed by resolution of pre-and post-slaughterhouse problems and application of modern technologies in future. Therefore, the most important point in the development of leather industry is the production of high quality product. Nevertheless, several problems such as holes resulting from a knife or flaying process, poor appearance due to distortion during drying because of uneven tension, vein marks where the blood was not completely drained, post-slaughter defects originating from bacterial and enzymatic breakdown due to improper curing, machine damage, lack of skills, absence of suitable conditions in modern abattoirs and grain crack which are affecting quality of product adversely during leather making processes are reflected on finished products and lead to economic losses (7).

Hides (cattle, buffalo, camel and horse) or skins (sheep, goat and calf) are mainly by-products of the meat and dairy industries. Since hides or skins are effective barriers against harmful bacteria throughout lifespan of an animal, flaying leads to removal of this protection. Therefore, it is necessary to preserve hides/skins after flaying against possible bacterial activities in slaughterhouses up to tanning processes. It has been reported that between 15 and 24 hours due to applied improper preservation, loosening of hides/skins and peeling on grain surfaces are inevitable (8-10).

Flaying is performed by a machine in slaughterhouses or by using a knife in local regions. Due to the flaying mistakes, economic losses have been reported up to $50 \%$ (11). Mwinyijah and Magero (2009) emphasized the significance of post-slaughter activities in leather quality and they reported at least $60 \%$ defects of hides and skins are related with post-slaughter processes due to handling and preservation mistakes (12). Blood, moisture, dirt and temperature etc. provide excellent milleu for microorganisms to grow which then lead to putrefaction of hides/skins. The raw hides/skins contain water more than half of their weight and this high water and protein content also trigger the growth of putrefactive bacteria $(8,13-17)$.

High-quality leather depends on the quality of raw hides/skins (7). After removal of animal pelt from carcass, it is preserved by dry salt or brine curing processes. Salt curing application is a cost-effective preservation method which is used traditionally in many countries including Turkey (1018). It has been indicated that raw hides have to be salted with 40-50\% salt (19). Although dry salt application controls development of resident or transient populations of microorganisms on hides/skins, this preservation method cannot prevent completely the growth of salt tolerant bacteria, slightly and halophilic bacteria and extremely halophilic archaea on the hides and skins. Salted hides/skins are a unique habitat for a wide variety of Gram positive and Gram negative bacteria and these opportunistic bacteria can attack easily to grain surface and flesh side of hides/skins via their extracellular enzymes $(10,18,20-27)$. Especially proteolytic and lipolytic archaea have may cause red heat, unpleasant odour, pinpricks, disruption of collagen fibers, hair loosening, hair loss, hole formation, irreversible damage on grain surface of skins/hides, abraded appearance, uneven dyeing etc. This penetration cause to putrefaction and hair slips following digestion of proteins of hides or skins $(9,20,28)$. Therefore, grain surface has a great importance for leather processsing. Therefore, sufficient sterile salt and antimicrobial agent are required to completely saturate hides to stop microbial growth.

The soaking process, which is the first important stage in the tanning process, is applied to salted or brine-cured hides and skins. The dry salt cured hides are soaked in water for a long time varying between tanneries. This process allows rehydration of hides/skins and they become more soft and flexible. In previous studies, a considerable number of bacteria were found in soaked hides, and soak liquor samples, 
probably due to preservation and soaking process mistakes (10, 20-31).

Therefore, it is necessary to determine encountered problems by tanners in detail and to produce economic solutions. For this purpose, we applied a questionnaire (28 questions) to leather technicians in Istanbul Organized Leather Industrial Zone, Turkey in both 2009 and 2018 to determine major problems and technical procedures on salted and soaked skins/hides.

\section{MATERIAL AND METHODS}

A questionnaire including 28 questions was prepared to determine the problems in preservation and soaking processes of skins/hides. The prepared questionnaire was applied face-to-face to leather technicians in twenty five tanneries in 2009 and ten tanneries 2018, in Istanbul Organized Leather Industrial Zone, Turkey. We could perform the questionnaire in only ten tanneries in 2018 due to decrease in the number of tanneries in Istanbul Organized Leather Industrial Zone. The collected data were compared according to the years (2009 and 2018). The applied questionnaire is given below.

\section{A Questionnaire}

Various problems arising during leather processing are reflected in the finished product and cause economic losses by affecting leather quality adversely. This questionnaire was carried out in order to determine the problems frequently encountered in the leather industry and to solve these problems scientifically. Our main objective in this survey is to solve the problems in the leather industry within the framework of University-Industry cooperation. The questionnaire containing following questions were used in this study.

1.How many years have you been working in the leather industry?

2.What kind of animal do you process?

$\square$ Cattle $\square$ Lamb $\square$ Sheep $\square$ Other (

3.Are you processing the imported hides/skins from foreign countries? If your reply yes please write the name of countries.

$\square$ Yes $\square$ No

4.How long do you store hides/skins before processing?

$\square$ 0-1 months $\square$ 1-3 months $\square$ 3-6 months

$\square$ 6-12 months $\square$ over 12 months.

5.What is the storage temperature?

$\square$ 0-10 ${ }^{\circ} \mathrm{C} \square 10-20^{\circ} \mathrm{C} \square 20-30^{\circ} \mathrm{C} \square \mathrm{I}$ do not know

6.Do you utilize used salt in curing process of hides and skins?

$\square$ Yes $\square$ No

7.Do you use brine solution more than once for brine-curing preservation of hides/skins?

$\square$ Yes $\square$ No

8.Do you use antimicrobials during salting of hides/ skins? If you use, can you write the names and content of active ingredients?

$\square$ Yes $\square$ No

9.Are you applying salt curing method in your tannery or are you taking salted raw hides/skins?

$\square$ Yes $\square$ No

If your answer yes to question 9, answer the questions 10 , 11 and 12 below. Otherwise, continue to answer Question 13 and following questions.

10. Where do you get hide and skin curing salt?

11.How much salt do you use for salt curing?

(In $\mathrm{kg}$ amount per a hide/skin)

12.Have you observed any color change in the salt used? (eg pink or yellow color instead of white)

$\square$ Yes $\square$ No

13. Which preservation method was used for your raw materials?

$\square$ Dry salt curing method $\square$ Brine curing method

14. Do you do fleshing process (removing hypodermis (fat) from hides/skins)?

$\square$ Yes $\square$ No

15. What changes have you observed on the salted skins and hides?

$\square$ Red heat $\square$ Bad odor $\square$ Hair loosening $\square$ Stains

$\square$ Degradation of flexibility $\square$ Holes

$\square$ Bacterial development $\square$ Fungi development

16. How long do you apply soaking process?

$\square$ 0-6 hours $\square$ 6-12 hours $\square$ 12-18 hours $\square$ 18-24 hours

$\square$ over 24 hours.

17. Does the temperature of the soaking liquor increase at the end of the process?

$\square$ Yes $\square 20-25^{\circ} \mathrm{C} \square 25-30^{\circ} \mathrm{C} \square \mathrm{No}$

18. How much is the volume of the soaking drum?

19. How much water and hide/skin do you use in the soaking drum?

20. What else do you add into the soaking drum?

21. Do you use antimicrobial agent in the soaking drum?

22. What type of antimicrobial agent (fungicide or 
bactericide)do you use in the soaking process, what are names and ingredients of it?

23. How much antimicrobial agent do you add into the soaking drum?

24. Did you observe bad odor in the soaking drum?

$\square$ Yes $\square$ No

25. What is temperature of soaking liquor?

26. What is the $\mathrm{pH}$ of soaking liquor?

27. What are the problems detected in the finished product?

$\square$ Hole formation $\square$ Stain formation $\square$ Dyeing problems

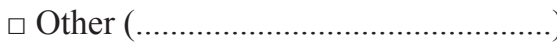

28. What are the other issues you observed that are not included in this questionnaire?

\section{RESULTS AND DISCUSSION}

A number of problems encountered during the processing of raw hides/skins are reflected in the finished products and affect the quality of product adversely which lead to economically serious losses. For this reason, it is necessary to determine the problems encountered in the leather industry and to solve these problems. Hence, we applied two questionnaires in 2009 and 2018 to determine whether or not any change in problems of leather industry according to years. It was determined that majority of leather technicians that we interviewed (72\% in 2009 and $90 \%$ in 2018) worked in the leather industry for more than 10 years. This result indicates that highly qualified technicians are working in leather industry. While the most processed hides/skins in the tanneries were cattle, sheep, lamb and goat in 2009, most tanneries used cattle hides in 2018. This may be attributed to its usage in the world market, economic reasons, decreased preference of leather by people, increased interest in artificial leather production etc. People cannot afford buying leather and leather goods due to their high prices, especially in developing countries. In addition, fur production has lost its popularity due to protection of animal rights. It was observed that $92 \%$ of the tanneries prefer hides/skins from foreign countries and most preferred country is Greece $(\mathrm{n}=7)$, followed by the U.K. $(n=4)$ and America $(n=4)$. It has been determined that the majority of hides/skins ( $83 \%$ ) comes from abroad in 2009 . On the other hand, the tanneries reported that they generally process local cattle hides from Turkey but sometimes imported hides from Armenia, Turkmenistan, Kazakhistan, Kenya, Azerbaijan, Iraq, Serbia, America, and rarely from Russia in 2018. In 2009, 20\% (1-3 months) and 4\% (6-12 months) of tanneries were storing raw hides more than one month. In 2018, all tanneries reported that they do not store raw hides more than one month. However, there is no information about how long they store in warehouses. The long storage period may cause problems on raw hides and skins due to bacterial growth. It has been reported that halophile and non-halophile microorganisms may cause serious damages on salted skins/hides $(9,28,32)$. In previous studies, a considerable number of non-halophile and halophile bacteria and archaea were found in salted and soaked hides, and soak liquor samples, probably due to preservation and soaking processes mistakes. Bacillus. licheniformis, B. pumilus, Enterococcus faecium, Pseudomonas luteola, Aerococcus viridans, Bacillus mycoides and Staphylococcus cohnii were reported to have both protease and lipase activities $(10,11$, $21,22,26)$. Aslan et al. $(2011,2012)$ reported the growth of several Gram-positive bacterial species belonging to the genera of Aerococcus, Aneurinibacillus, Bacillus, Brevibacillus, Enterococcus, Geobacillus, Kocuira, Lactococcus, Paenibacillus, Streptococcus, Staphylococcus and Virgibacillus and Gram-negative bacterial species belonging to the genera of Acinetobacter, Aeromonas, Alcaligenes, Burkholderia, Citrobacter, Comamonas, Edwardsiella, Enterobacter, Escherichia, Hafnia, Klebsiella, Mannheimia, Pasteurella, Proteus, Pseudomonas, Salmonella, Serratia, Sphingomonas, Stenotrophomonas, Vibrio and Yersinia from salted hides indicating that salt curing process were not sufficient $(10,22)$. These damages are mostly irreversible and cannot be ameliorated in following stages of tanning. While salt-curing, brine-curing and both methods were being used in 2009, only salt-curing method is used in 2018. The reason for application of only salt-curing method in 2018 is that it is a traditional method for our country. According to our questionnaire results, we have determined that most tanneries do not prefer imported hides/skins in 2018. On the other hand, brine-curing method is generally preferred in other countries. We determined that salt and brine which have used for hide/ skin preservation are not used more than once in both 2009 and 2018.

When the application of antimicrobial agent was asked to apply to skin technicians during the salt-hardening process, it was determined that the percentage of antimicrobial users was $36 \%$ and that of non-users was $64 \%$ in 2009 . On the other hand, it was reported in 2018 that tanners did not use antimicrobial agents. This result emphasizes that salt-curing method must be applied properly in warehouses. The most striking point is that salt is applied non-homogeneously during hide preservation but sufficient salt should be applied to raw hides and skins for complete saturation to inhibit bacterial growth. It has been indicated that raw hides should be salted with $30-50 \%$ salt. In our previous study (25), we isolated proteolytic and lipolytic extremely halophilic archaea 
$\left(10^{5}-10^{6} \mathrm{cfu} / \mathrm{g}\right)$ from the salted hide samples in considerable numbers. We observed proteolytic and lipolytic extremely halophilic archaea in the most samples of salt and salted hides. We found that archaeal counts were low $\left(10^{2}-10^{4} \mathrm{cfu} / \mathrm{g}\right)$ in the salt samples whereas they were high in the salted hides $\left(10^{2}-10^{6} \mathrm{cfu} / \mathrm{g}\right)(25)$. These results points to inadequate salt-curing application. Therefore, brine-curing method applied together with antimicrobial agent may diffuse homogeneously into raw hides/skins and prevent the growth of non-halophile and halophile bacteria.

The tanners stated that commercially available mineral salt is used for skin/hide preservation and origin of salt is Lake Tuz. No color change (pink etc.) in salt, used in hide preservation, was reported by tanneries. Pink or red color in salt are related to the growth of halophilic archaea. It has been emphasized that salt must be free of copper salts and free of halophile microorganisms to prevent stains on the skin (33). Birbir et al. (2004) evaluated the extremely halophilic archaeal numbers of salt samples harvested from Tuz Lake, Kaldırım, Kayacık Salterns, and Tuzköy Mine and reported as $10^{4}-10^{7} \mathrm{cfu} / \mathrm{g}, 10^{5}-10^{7} \mathrm{cfu} / \mathrm{g}, 10^{5} \mathrm{cfu} / \mathrm{g}$, and $10^{5}$ $10^{6} \mathrm{cfu} / \mathrm{g}$, respectively. They also studied on brine samples that collected from same locations mentioned above and they found $10^{3}-10^{5} \mathrm{cfu} / \mathrm{mL}$ extremely halophilic archaea. These microorganisms had also proteolytic and lipolytic activities (34). Therefore, salt must be regularly checked for any color change to avoid microbial damages originating from halophilic archaea.

Moreover, fleshing is critical importance for salt penetration into the hide. If fleshing is not done, antimicrobial agent cannot be effective on skin/hide due to fat layer and other residues on soaking process. In our country, fleshing is performed after liming process and not on raw hide. Meat on raw material means to be enriched nutrient for microorganisms. Therefore, microbial growth and their possible damages on leather is inevitable. In 2009, most of 25 tanneries supplied salted hides/skins from warehouses except 5 tanneries. Three of 25 tanneries reported that they used extra salt for preservation. On the other hand, 17 of 25 tanneries did not apply extra salt on salted hides. In 2018, we determined that tanners process salted hides directly without adding extra salt application. When amount of salt applied by tanneries for salt-curing preservation of hides was asked in 2009 and 2018, it was detected that salt application varied between tanneries ( 5 of 8 tanneries applied salt randomly, 1 of 8 tanneries $4 \pm 1 \mathrm{~kg}$ per each hide, 1 of 8 tanneries $1 / 3$ of skin weight, and 1 of 8 tanneries $1 / 5$ of the skin weight).

We determined that the soaking process was generally carried out for 12-18 hours in tanneries in both 2009 and
2018. This process time can vary according to countries and preservation methods. The researchers have stated that duration of soaking process should be at least 1.5 hours and maximum 48 hours $(13,35)$. The duration of the soaking process should not be too long. Bacteria secrete a variety of extracellular enzymes, leading to damage in skins/hides. They break down proteins on the skin with protease enzymes, fats with lipase enzymes, and collagen fibrils with collagenase enzymes. On the other hand, the generation time of most bacteria in ambient conditions can range from 0.5 to 6 hours (36). Taken into consideration of generation time of bacteria, it is inevitable that bacteria in soak liquor will reach a significant number within 12-18 hours. The efficacy of antimicrobial agent does not remain after a certain period of time. In our previous study, proteolytic and lipolytic bacteria $\left(10^{5}-10^{8} \mathrm{cfu} / \mathrm{g}\right)$ were substantially high in $97 \%$ of the soaked hide samples and they were high only in $42 \%$ of the soak liquors $\left(10^{5}-10^{6} \mathrm{cfu} / \mathrm{g}\right)$. Therefore, it is essential to add antimicrobial agent to soak liquor at regular intervals in this long soaking process (27). In soaking process, a wide variety of chemicals are used such as bactericides, enzymes, soda, surfactants (tensid = soap) etc. The surfactants may have anionic, nonionic, cationic and amphoteric properties. Nonionic surfactants are preferred due to no binding to skin. Moreover, bactericide, wetting agent, enzyme, fungicide, arsenic sulphur, salt lime, degreasing agent, washing agents for fur, anti-blood vein agent, aldehyde, nonionic surfactant, $\mathrm{pH}$ regulator, soap, soda ash, ammonium sulphate and foril (11). Most tanneries reported that they applied antimicrobial agent at doses of 0.2-0.4 \% g/l in both 2009 (64\%) and $2018(70 \%)$. Sixty percent of twenty-five tanneries notified unpleasant odor in soaking drum in 2009. On the other hand, $30 \%$ of ten tanneries reported same complaint in 2018. Richardson (1958) indicated that the formation of bad odor in soaking drum was associated with bacterial growth (37). In our previous study, the number of bacteria was taken under control by increasing the concentration of antimicrobial substance (didecyldimethylammonium chloride) to $0.4 \mathrm{~g} / \mathrm{l}$ of in first and $0.8 \mathrm{~g} / \mathrm{l}$ in main soaking process and genera of Bacillus, Brevibacillus, Enterobacter, Pseudomonas, Enterococcus, Lactococcus, Aerococcus, Vibrio, Staphylococcus, Kocuria and Micrococcus were isolated in the main soak liquor containing antimicrobial substance. We detected that bacterial activity was considerably high in the salted and soaked hides and also the concentration of antimicrobial substance used in the soaking process was insufficient. For this purpose, antimicrobial agents may be applied at regular intervals to inhibit bacterial growth (27). It is also known that bacteria can resist against several antimicrobial agents. They can easily transfer their resistance genes 
via horizontal gene transfer (38). In this respect, alternative agents or strategies may be helpful. Our questionnaire results of year 2009 showed that temperature of soaking liquor was not sufficiently taken into consideration. Seven tanneries notified that they used directly refining water in soaking process without control. Two tanneries set temperature of soaking process to $18-20^{\circ} \mathrm{C}$ and the other two tanneries adjusted to $20-24^{\circ} \mathrm{C}$. One tannery reported the temperature they adjusted during soaking process as $28-32{ }^{\circ} \mathrm{C}$. In 2018 , most of the tanneries reported that they adjust the temperature of soaking process to $24-28{ }^{\circ} \mathrm{C}$ except one tannery (22 ${ }^{\circ} \mathrm{C}$ ). According to this information, tanners are more aware about the effect of temperature on leather quality. Wodroffe (1957) found that even at $5{ }^{\circ} \mathrm{C}$, bacteria could grow on soak liquor, suggesting that increasing a few degrees of soak liquor would reduplicate number of bacteria. For this reason, it has been emphasized that temperature of soak liquor should be low and not exceed $10{ }^{\circ} \mathrm{C}(39)$. It has been stated that damages on hides may occur when temperature of soak liquor is between $18-24{ }^{\circ} \mathrm{C}$. It has been also reported that semi-transparent areas could be seen when temperature of soak liquor is $18-24^{\circ} \mathrm{C}(37)$. When the $\mathrm{pH}$ values of soaking process were asked, tannery technicians answered considerably different values in 2009 . On the other hand, most of the technicians reported that the $\mathrm{pH}$ value of soaking process was adjusted to 9-9.5 except two tanneries $(\mathrm{pH}=6$ and $\mathrm{pH}=12$ ) in 2018. It has been stated that $\mathrm{pH}$ of soak liquor should not exceed 10.5. It has been emphasized that higher $\mathrm{pH}$ values may cause swelling on hide surface, causing difficult penetration of liming materials and also forming nubuck appearance. It has been reported that strong alkaline substances catalize soaking process but cause to decrease in the strength of fibers, holes in grain surface and opaque appearance of leather $(40,41)$. Tanners informed us for unwanted defects observed on skins/hides as red heat, unpleasant odour, spot, hair loss, decreased elasticity, hole, bacterial and fungal growth, uneven dyeing, preservation and flaying mistakes, bloodstain, burns due to manure.

\section{CONCLUSIONS}

To our knowledge, the present study is the first detailed study which detects and compares problems in leather indursty in both 2009 and 2018. We observed that the problems (especially unwanted defects observed on skins/ hides as red heat, unpleasant odour, spot, hair loss, decreased elasticity, hole, bacterial and fungal growth, uneven dyeing, preservation and flaying mistakes, bloodstain, burns due to manure) are the same in 2009 and 2018. Therefore, we must take precautions to eliminate these defects. Temperature and
$\mathrm{pH}$ control must be done regularly in soaking process, flaying, preservation and soaking processes must be applied properly. As a conclusion, we should focus on raw material to produce best quality of leather. The ambient conditions of slaughterhouses must be improved and flaying process should be performed by high skilled employees. The most pronounced mistake in preservation of raw hides/skins is insufficient and non-homogenous salting. The standardized salt application must be carried out. The parameters affecting leather quality such as temperature, $\mathrm{pH}$ etc. must be controlled regularly, hides/skins with pink or red colored areas should be discarded and others should be salted with antimicrobial agent and stored in cold at $5{ }^{\circ} \mathrm{C}$. Antimicrobial agents may be applied at regular intervals to inhibit microbial growth. We believe that when these issues and essential precautions are taken into consideration, mostly encountered problems could be solved.

\section{ACKNOWLEDGEMENT}

This paper was supported by the Scientific Research Project Commission of Marmara University, Project No. FENDKR-290506-0113. We thank to the Scientific Research Project Commission, the technicians working in tanneries in Istanbul Organized Leather Industrial Zone, Turkey.

\section{REFERENCES}

[1] Uysal, G. (2002). Türkiye ekonomisinde deri ve deri mamulleri sanayinin yeri ve öneminin araştırılması. Turk J. of Vet and An. Sciences, 26, 671-678.

[2] Thanikaivelan, P., Rao, J.R., Nair, B.U. \& Ramasami, T. (2005). Recent trends in leather making: processes, problems, and pathways. Critical Reviews in Environmental Science and Technology, 35(1), 37-79.

[3] İstanbul Sanayi Odası. (2011). Deri ve deri ürünleri sanayisinin Avrupa Birliği’ne uyum sürecinde sektör rehberleri.

[4] Çaglayan P. (2015). Characterization of moderately halophilic bacteria found on the sheep and goat skins. Doctoral thesis, Marmara University,Turkey, s. 4-5.

[5] ITKIB General Secretariat of Istanbul Textile and Apparel Exporters' Associations (February 2018). Leather and Leather Product Sector, s. 1-22.

[6] Deri ve deri ürünleri imalatı sanayi, küresel rekabette istanbul sanayi odası meslek komiteleri sektör stratejileri projesi, ISO, Yayın No: 2015/7.

[7] Kahsay, T., Negash, G., Hagos, Y. \& Hadush, B. (2015). Pre-slaughter, slaughter and post-slaughter defects of skins and hides at the Sheba Tannery and leather industry, Tigray region, northern Ethiopia. Onderstepoort Journal of Veterinary Research, 82 (1), 01-07. 
[8] Bilgi, S.T., Yapici, B.M. \& Yapici, A.N. (2009). Determination of bacterial and fungal numbers in floats of pre-tanning operations. African Journal of Biotechnology, 8 (8), 1602-1607.

[9] Birbir, M. \& Bailey, D.G. (2000). Controlling the growth of extremely halophilic bacteria on brine cured cattle hides. Journal of the Society of Leather Technologists and Chemists, 84 (5), 201-204.

[10] Aslan, E., \& Birbir, M. (2011). Examination of Gram positive bacteria on salt-pack cured hides. Journal of the American Leather Chemists Association, 106 (12), 372-380.

[11] Yazi, D. (2009). Examination of bacterial population in salt, salted and soaked raw hides. Doctoral thesis, Marmara University, Türkiye, s.1-208.

[12] Mwinyijah, M. \& Magero, J. (2009). The dilemma in marketing of camel (Camelus dromedarius) hides in Kenya: Paper Presented at the 14th Annual Kenya Camel Forum (KCF) Moyale.

[13] Rangarajan, R., Didato, T.D. \& Bryant, S. (2003). Measurement of bacterial populations in typical tannery soak solutions by traditional and new approaches. Journal of the American Leather Chemists Association, 98, 477-485.

[14] Kanagaraj, J. \& Chandra Babu, N.K. (2002). Alternatives to salt curing techniques: a review. Journal of Scientific \& Industrial Research, 61 (5), 339-348.

[15] Kanagaraj, J., Sundar, V.J., Muralidharan, C. \& Sadulla, S. (2005). Alternatives to sodium chloride in prevention of skin protein degradation-a case study. Journal of Cleaner Production, 13, 825-831.

[16] Kanagaraj, J., Sastry, T.P. \& Rose, C. (2005). Effective preservation of raw goat skins for the reduction of total dissolved solids. Journal of Cleaner Production, 13, 959-964.

[17] Kılıçoğlu, S. (1991). Ham deri. Dericilik Araştırma Enstitüsü Yayınları, Pendik, İstanbul, Türkiye, 6, 65.

[18] Birbir, M. (1997). Investigation of salted-cured France and Russian hides for halophilic bacteria. Journal of Turkish Microbiological Society, 27, 68-73.

[19] Kannan, K.C., Kumar, P., Rao, J.R. \& Nair, B.U. (2010). A novel approach towards preservation of skins. Journal of the American Leather Chemists Association, 105 (11), 360-368.

[20] Bailey, D.G. \& Birbir, M. (1993). A study of the extremely halophilic microorganisms found on commercially brine-cured cattle hides. The Journal of the American Leather Chemists Association, 88, 285-293.

[21] Birbir, M. \& Ilgaz, A. (1996). Isolation and identification of bacteria adversely affecting hide and leather quality. Journal of the Society of Leather Technologists and Chemists, 80, 147153.

[22] Aslan, E. \& Birbir, M. (2012). Examination of Gram-Negative bacteria on salt-pack cured hides. The Journal of the American Leather Chemists Association, 4 (107), 106-115.

[23] Caglayan, P., Birbir, M., Sanchez-Porro, C. \& Ventosa, A. (2017). Screening of industrially important enzymes produced by moderately halophilic bacteria isolated from salted sheepskins of diverse origin. Journal of the American Leather Chemists Association, 112 (6), 207-216.

[24] Caglayan, P., Birbir, M., Sánchez-Porro, C., \& Ventosa, A. (2018) .Detection of industrially potential enzymes of moderately halophilic bacteria on salted goat skins. Turkish Journal of Biochemistry, 43 (3), 312-322.

[25] Berber, D. \& Birbir, M. (2010). Examination of bacterial populations in salt, salted hides, soaked hides and soak liquors. Journal of the American Leather Chemists Association, 105 (10), 320-326.

[26] Berber, D., Birbir, M., \& Mertoglu, B. (2010). Examination of Archaeal and Bacterial populations in salt, salted and soaked hide and soak liquor samples via fluorescent in situ hybridization. Journal of the Society of Leather Technologists and Chemists, 94 (6), 259-261.

[27] Berber, D., Birbir, M. \& Hacioglu, H. (2010). Efficacy assessment of bactericide containing didecyldimethylammonium chloride on bacteria found in soak liquor at different exposure times. Journal of the American Leather Chemists Association, 105 (11), 354-359.

[28] Bailey, D.G. \& Birbir, M. (1996). The Impact of halophilic organisms on the grain quality of brine cured hides, Journal American Leather Chemists Association, 91, 47-51.

[29] Bailey, D.G. (2003). The preservation of hides and skins. Journal of the American Leather Chemists Association, 98, 308319.

[30] Birbir, M., Kallenberger, W., Ilgaz, A. \& Bailey, G. (1996). Halophilic bacteria isolated from brine cured cattle hides. Journal of the Society of Leather Technologists and Chemists, 80, 87-90.

[31] Akpolat, C., Ventosa, A., Birbir, M., Sánchez-Porro, C. \& Caglayan, P. (2015). Molecular identification of moderately halophilic bacteria and extremely halophilic archaea isolated from salted sheepskins containing red and yellow discoloratios, The Journal of the American Leather Chemists Association, 110, 211-220.

[32] Haines, M.B. (1984). Quality rawstock. The Journal of the American Leather Chemists Association, 4, 164-173.

[33] Kallenberger, E.W. (1984). Halophilic bacteria in brine curing. The Journal of the American Leather Chemists Association, 79, 104-114.

[34] Birbir, M., Ogan, A., Calli, B. \& Mertoğlu, B. (2004). Enzymatic characteristics of extremely halophilic archaeal community in Tuzkoy Salt Mine, Turkey. World Journal of Microbiology and Biotechnology, 20, 613-621.

[35] Orlita, A. (2004). Microbial biodeterioration of leather and its control: a review. International Biodeterioration \& Biodegradation, 53, 157-163.

[36] Madigan, M.T., Martinko, J.M., Dunlop, P.V. \& Clarck, D.P. (2012). In: Brock Biology of Microorganisms, Thirteenth Edition, Pearson Benjamin Cummings., s.150-151. 
[37] Richardson, J. H. (1958). A laboratory screening test of bactericides for use in sheep pelt soaking pits. Applied Microbiology, 6 (2) 142-145.

[38] Birbir, Y., Uğur, G. \& Birbir, M. (2008). Inactivation of bacterial population in hide-soak liquors via direct electric current. Journal of Electrostatics, 66 (7-8), 355-360.

[39] Wodroffe, F.W. \& Parr, P.R. (1957). Note on bacteriological test on bobby calf skins treated with boric acid. Report on the eight annual conference of freezing works. Leather and Shoe Association, 38-39.

[40] http://dericilik.blogcu.com/4144149 (Erişim tarihi: Mayıs 2008).

[41] Tancous, J., Kallenberger, W., Buehrig, B. \& Hermann, L.S. (1996). Rehydration of brine cured hides. Leather, 21-28. 